\title{
An Empirical Assist To Determine Whether An Activity Is Engaged In For A Profit
}

\author{
Ted D. Englebrecht, Louisiana Tech University, USA \\ W. Brian Dowis, Georgia Southern University, USA \\ Justin S. Cox, University of Mississippi, USA
}

\begin{abstract}
Taxpayers engage in activities for both tax and nontax reasons. Some of these undertakings are geared to earn a profit. Other activities provide personal pleasure and recreation. Regardless of the activity type, expenses are incurred and can be substantial. Depending on the type of engagement, profit may or may not be achieved. Naturally, many of these pursuits are undertaken for a number of consecutive years. Because of the tax benefits these activities possess, this issue remains highly litigated and closely scrutinized by the Internal Revenue Service. This study investigates the guidance delineated by the Service and creates a model of the significant variables that affect the judiciary's decision-making. Backwards stepwise logistic regression is used to create the model. Chi-square is also used to determine statistical significance between the decision rendered and judge's gender. Also, political affiliation of the judge is examined. The one variable (manner in which the taxpayer carries on an activity) model created correctly classifies $96.3 \%$ of the decisions made in the U.S. Tax Court. Additionally, a statistically significant difference is found between male and female judges. However, no difference is found based on the political affiliation of the judge.
\end{abstract}

Keywords: Hobby Activities; Judge Gender; Tax Court

\section{INTRODUCTION}

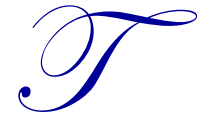

axpayers pursue activities for a multitude of reasons. Some of these endeavors are participated in to earn a profit, whereas, other activities provide personal enjoyment, fulfillment, and recreation indicating a hobby activity. Commonly litigated activities include horse related activities (such as horse breeding, horse racing, training, showing, etc.), cattle/farming activities (such as cattle ranching, organic apple orchard farming, etc.), and racing activities (such as drag and stock car racing, etc.). Irrespective of the activity type, expenses are incurred and can reach substantial amounts. Profit may or may not result depending on the type of activity. Also, many of these activities are conducted year after year. The tax treatment of for profit and/or hobby loss activities can provide significant tax benefits or not. Because of the guidance the Internal Revenue Service (hereinafter referred to as the IRS, Commissioner, or Service) has delineated in the U.S. Treasury Regulations, taxpayers have been provided with nine factors that help distinguish between a hobby and a for-profit activity. However, no one factor is sufficient in and of itself. When an activity is deemed a hobby, the losses deductible are limited to the amount of hobby income. Conversely, losses arising from an activity entered into for-profit can exceed the income. Therefore, the tax savings between the two different types of classifications can significantly affect an individual's income tax liability. Also, this issue continues to be frequently contested in court. Until a Supreme Court ruling is made providing more explicit assistance or new guidance is promulgated by the Service, there will continue to be ambiguity in this highly litigious area of taxation.

The rest of the paper is broken down into the following sections. The first section discusses the background of hobby loss activities and the corresponding authority. Section two highlights the prior research and the research questions. The third section explains the research methodology. The fourth section analyzes the results and the last section presents the conclusions, limitations, and future research opportunities. 


\section{BACKGROUND}

\section{IRC 183}

The Internal Revenue Code addresses activities not engaged in for profit (hereinafter referred to as hobby activities) in Code Section 183. It provides that deductions of an activity, entered into either by an individual or an $\mathrm{S}$ corporation not engaged in to make a profit, will not be allowed unless it falls under $\$ 183(\mathrm{~b})$. Section 183(b)(1) permits deductions for expenses incurred regardless of the nature of the activity. Additionally, Section 183(b)(2) describes the allowance of deductions that would be permitted if the activity was a for profit activity but only up to the amount of the gross income generated from that activity. That is, the deductions would be allowable under $\S 162$ or $\$ 212$. An activity's past financial success or failure plays a role in determining its current tax status. When the activity's gross income for three or more taxable years during the last five consecutive tax years is greater than the associated deductions from the same activity, then the activity will be deemed for profit. If the activity relates to showing, training, breeding, or racing horses, the time period is two years of the preceding seven consecutive tax years.

\section{Treasury Regulation Section $\mathbf{1 . 1 8 3}$}

Treasury regulations and rulings, as administrative authority, serve to clear up ambiguity when the Code fails to address particular tax issues. Treasury Reg. Sec. 1.183-2(b) delineates factors that must be considered when determining whether an activity is a hobby or an activity is engaged in for profit. Moreover, all of the facts and the circumstances surrounding the activity must be weighed and no single factor is indicative of a certain type of classification. The following table depicts the factors the Service uses to determine an activity's status.

Figure 1. Specific Factors For Determining Hobby Losses in U.S. Treasury Reg. Sec. 1.183-2(b)*
1) Manner in which the taxpayer carries on the activity
2) The expertise of the taxpayer or his advisors
3) The time and effort expended by the taxpayer in carrying on the activity
4) Expectation that assets used in activity may appreciate in value
5) The success of the taxpayer in carrying on other similar or dissimilar activities
6) The taxpayer's history of income or losses with respect to the activity
7) The amount of occasional profits, if any, which are earned
8) The financial status of the taxpayer
9) Elements of personal pleasure or recreation

*Each factor is discussed in detail in Appendix A

EXAMPLE: The following illustration demonstrates the difference between tax consequences of an activity that is deemed engaged into for profit and a hobby activity.

Chuck Morris works full-time as an accountant for TaxSavers Inc. Chuck provides tennis lessons on the weekend. He teaches around 2 hours each weekend (approximately 50 weekends each year) and purchases all of the supplies and equipment he uses in the activity. His hourly rate is $\$ 20$ an hour. Purchases of tennis balls, targets, instructional equipment, ball feeding machine, court time, and advertising expenses total $\$ 12,000$. His revenue totals $\$ 2,000$. Therefore, he incurs a $\$ 10,000$ loss. Also, Chuck does not have enough itemized deduction items to itemize and he is single with no dependents. 


\begin{tabular}{|c|c|c|}
\hline & Activity Engaged for Profit & Hobby Activity \\
\hline $\begin{array}{l}\text { Gross Income Before Losses from Activity (includes } \$ 2,000 \text { of } \\
\text { income from tennis lessons) }\end{array}$ & $\$ 102,000$ & $\$ 102,000$ \\
\hline Losses from Profit Activities & $(\$ 12,000)$ & $\underline{0}$ \\
\hline Adjusted Gross Income & $\$ 90,000$ & $\$ 102,000$ \\
\hline $\begin{array}{l}\text { Less: Greater of Standard Deduction or Itemized Deduction (using } \\
2016 \text { standard deduction amount) }\end{array}$ & $(\$ 6,300)$ & $(\$ 6,300)$ \\
\hline $\begin{array}{l}\text { Less: Personal and Dependency Exemption (using } 2016 \text { exemption } \\
\text { amount) }\end{array}$ & $(\$ 4,050)$ & $(\$ 4,050)$ \\
\hline Taxable Income & $\$ 79,650$ & $\$ 91,650$ \\
\hline Total Tax Liability (using 2016 Tax Rate Schedule) & $\$ 15,683.75$ & $\$ 18,698.75$ \\
\hline
\end{tabular}

As indicated above, Chuck's income tax liability increases by $\$ 3,015(\$ 18,698.75-\$ 15,683.75)$ based on his activity being classified as a hobby activity compared to an activity engaged for profit. The size of the loss, whether large or small, can have significant tax implications for taxpayers incurring such losses.

\section{PRIOR RESEARCH AND RESEARCH QUESTIONS}

\section{Profit Activity/Methodology Studies}

The Previti, Kleinsmith, and Previti (2016) article examined the hobby loss dilemma by comparing two specific cases litigated in the U.S. Tax Court. For each decision, the nine factors were weighed explaining whether the factor favored the IRS (not for profit) or the taxpayer (for profit). The two cases included Metz v. Commissioner ${ }^{1}$ and Craig v. Commissioner. ${ }^{2}$ Additionally, each factor was thoroughly explained and planning points were discussed. Moreover, categories of activities with the highest likelihood of attracting the Service's attention were also outlined. Last, the researchers provided that the taxpayer should conduct the undertaking in a businesslike manner and document as much as possible to clearly indicate a for-profit activity.

Research conducted by Siddiqui (2013) analyzed the hobby loss rule, specifically the Storey v. Commissioner case. The litigated activity was documentary filmmaking. The taxpayer was an attorney who decided to produce a film focused on a singing group named Up with People. Each of the nine factors was weighed in turn. Red flag activities and tips for taxpayers were delineated. However, no statistical tools were used in this article.

The Brennan (2005) study investigated the hobby loss rules specifically in the forum of the Tax Court. First, the regulatory environment surrounding activities engaged in for profit was discussed. Also, no statistical methods were used in this study but cases were examined. For each case, nine factors were outlined and the courts weighing of the factors were identified. Additionally, each factor was explained and analyzed. The total number of cases included in this study was 61 cases consisting of 65 activities. This research concludes the taxpayer is at a disadvantage when trying to litigate the hobby loss issue.

The Burns and Groomer (1983) article studied the business/hobby controversy, specifically in the U.S. Tax Court (Board of Tax Appeals was the judicial arena for the cases decided prior to 1940). Their data consisted of 151 cases spanning 1920-1980. The three specific timeframes examined included 1920-1980. 1920-1969, and 1970-1980. Multiple discriminant analysis with a stepwise procedure and a postulated procedure was used by the researchers to create factors indicative of either a successful taxpayer challenge or an IRS victory. The three phases resulted in classification rates with the stepwise model of 98\% (1920-1980), 97.4\% (1920-1969), and 97.1\% (1970-1980). The postulated model classification rates were 86.1\% (1920-1980), 82.1\% (1920-1969), and 88.2\% (1970-1980). Additionally, only farming-oriented activities were included. The model began with 38 variables, of which 28 came from the regulations and ten were taken from court cases. The 1920-1980 time period contained seven variables in the stepwise model and five variables in the postulated model. The time span of 1920-1969 stepwise model consisted of six variables whereas the postulated model only had five variables. Last, the 1970-1980 time frame had four

\footnotetext{
${ }^{1}$ Metz v. Commissioner, TC Memo 2015-54

${ }^{2}$ Craig v. Commissioner, TC Summary Opinion 2013-58
} 
variables in the stepwise model and six variables in the postulated model. The overall results provided evidence the regulation variables receive more attention when litigating the business/hobby controversy.

In the Robison (1983) article, the researcher utilized a 40 variable model to determine which variables are most important in deciding an activity's classification. The statistical methodology implemented was probit analysis. The data consisted of cases spanning 1955 through mid-1981 heard in the U.S. Tax Court resulting in 170 observations. The final model was comprised of five factors or characteristics. These significant attributes were 1) the activity is conducted in a businesslike manner, 2) elements of personal pleasure or recreation do not constitute a significant part of the activity, 3) the taxpayer has prior experience in the activity and/or consults with others both prior to and after entry into the activity, 4) the activity has previously generated profit or its future profit potential is good, and 5) the taxpayer spends a significant amount of time and effort on the activity or employs others to do so. Once the model was created, it was able to predict a holdout sample of 57 observations with $93 \%$ accuracy. Additionally, evidence was found showing cases were decided in a consistent manner.

Research by Burns and Groomer (1980) focused on the business/hobby controversy from its enactment. Moreover, the paper's objective was to highlight the nine factors delineated in the regulations while forming recommendations and insight based on the judicial decision-making patterns. Throughout the analysis, various cases were used in either showing what favors or hurts a taxpayer's position. Also, Tax Court decisions from the 1970s were discussed throughout to assist in the analysis. The researchers concluded with a list of the minimum actions taxpayers should take when arguing an activity with a profit motive. Furthermore, seven extra tips were provided in addition to emphasizing five warnings to consider.

\section{Gender/Political Affiliation Literature}

In the Englebrecht and Dowis (2016) article, the topic of employee versus independent contractor was examined. Specifically, the 20 factors designed to assist employers in determining worker classification outlined by the IRS, gender, political affiliation of the judges, and industries of the companies were included in the study. A model was created using backwards stepwise logistic regression. A model of three factors (supervision / instructions, right to discharge, and continuing relationship) was generated, and it was capable of predicting $93 \%$ of the rulings made by the U.S. Tax Court during 1988-2014. Also, a statistically significant difference was found between female and male judges. No difference was indicated based on the political affiliation of the judges. Additionally, significant differences were found based on the type of industry involved in the cases.

In Welch (1985), the voting patterns of male and females in the House of Representative were investigated. The time period examined included 1972 through 1980. The independent variable consisted of the gender of the judge with the dependent variable being the Congressional Quarterly's coalition support score. The findings concluded a difference in the way male and females vote with males voting in a less liberal direction than females. Additionally, the voting behavioral differences have narrowed over time.

Research conducted by Walker and Barrow (1985) analyzed the types of judges in the U.S. District Court. The focus of their research was nontraditional judges which meant black and female judges. A "matched pair" strategy was used dividing the groups into twelve male-female pairs. No gender differences were found in cases involving criminal policy and women's rights. Conversely, results indicated that females show less of a tendency to render decisions in favor of personal liberty claims and minority policy. As a result, females exhibit an inclination to make rulings favoring government entities.

In Jackson, Pippin, and Wong (2013), valuations of assets and businesses were examined in estate tax cases. Multiple regression and a correlation matrix were the methodologies implemented. In the combined cases sample, the findings indicate four significant variables including political affiliation. The results from the combined cases sample indicate that the conservative appointee favors the taxpayer. 


\section{Research Questions}

The decision to challenge a ruling given by the Service requires careful thought and planning. Additionally, because the U.S. Tax Court does not require a paying of the deficiency prior to litigation in court, a decision to move forward with weak evidence can result in owing the same deficiency accompanied with interest and penalties. Therefore, adequate structuring of the pursued activity and proper documentation may not only end in a successful IRS challenge but potentially a lower chance of a detailed IRS audit. Since the factors and additional information is readily accessible to taxpayers, an analysis of hobby loss judicial decisions can provide warranted insight to taxpayers across the United States. The need in this area of taxation leads to the following research question:

RQ1: Can a viable model be created consisting of less than the nine factors provided in the U.S. Treasury Regulations?

A second area of inquiry in this research is the judge's gender. The decision to litigate can be a difficult one because of the time and cost it requires. Moreover, understanding the chance of success must also be weighed when determining whether to challenge the IRS in court. Currently, the U.S. Tax Court is composed of 32 total judges. Of the 32 judges who preside over a tax issue, 24 are male and eight are female. Therefore, if a difference does exist between the decision-making of a male and female judge, this research can provide guidance into how a judge will rule. Prior literature has found statistically significant differences between male and female judges (Englebrecht \& Dowis, 2016; Welch, 1985; Walker \& Barrow, 1985). This previous evidence posits the next research question:

RQ2: Is there a statistically significant difference between how male and female judges decide hobby loss activity cases?

A third part of this study examines the effect of political affiliation on the judges' renderings. Political affiliation of regular and senior U.S. Tax Court judges is determined by the political party of the original appointing president. If the judge is a Special Trial Judge, political affiliation of the president when the judge is selected as a Special Trial Judge is used. This information advances the last research question:

RQ3: Is there a statistically significant difference between Republican appointed U.S. Tax Court judges and Democratic appointed U.S. Tax Court judges?

\section{METHODOLOGY}

\section{Logistic Regression}

Logistic regression is a useful instrument when multiple regression cannot be implemented based on the nature of the data. Also, logistic regression portrays the likelihood the dependent variable is equal to 1 granted the predictor variables. Additionally, since the dependent variable in the current study is binary and not continuous, logistic regression is the most appropriate statistical tool to use (Johnson, 1998). The dependent variable is a decision that the activity is a hobby or that the activity is engaged into for profit. This variable is coded "0" if the decision is ruled for the taxpayer and thus deemed to be an activity engaged for profit. Conversely, a coding of " +1 " represents an IRS victory and a decision that the activity is a hobby. The independent variables in the predictive model are the factors outlined in U.S. Treasury Regulation 1.183-2(b). Each factor is coded " -1, , " 0 ," or " +1 ." The "- 1 " indicates the factor weighs in favor of the taxpayer representing an activity is engaged into for profit. The " 0 " signifies the factor weighs neither in favor of the taxpayer or the IRS and does not impact the decision made by the court. Last, the " +1 " implies the factor weighs in favor of the IRS and the activity is a hobby.

The data was collected from the RIA Checkpoint Tax Service. The sample is composed of all of the U.S. Tax Court cases rendering a decision on whether an activity is engaged into for a profit or not under IRC $\S 183$. The years under examination span from 1990 to 2014 ( 25 years) totaling 124 cases and 135 decisions (these multiple decision cases are noted in the Appendix B case listing). Several cases include multiple decisions on multiple activities. The majority of cases involve horse activity (this type of endeavor receives preferential treatment by the Service) which comprises $40 \%$ of all the activities brought before the judiciary. Other frequently litigated activities involve farming, racing, art, airplanes, and boats. The activities are grouped into 28 different types. Moreover, each case was read and coded by 
one of the researchers and then verified by another researcher to confirm the factors' codings. This is the first article, based on searching the current literature, which builds a model using the factors depicted in Regulation 1.183-2(b) while also examining the impact of judge gender and political affiliation.

\section{Chi-Square}

A Chi-square test is a test that determines whether a statistical difference is present between the estimated and observed covariance matrices. Also, it has been described as "the only measure that has a direct statistical test as to its significance" (Hair, Black, Babin, Anderson, \& Tatham, 2006, pg. 706). A Chi-square test is used in this study to determine if a statistically significant difference exists on how decisions are made based on the judge's gender. A decision is deemed in the IRS's favor if the activity is found to be a hobby. On the other hand, a for-profit decision would be deemed in favor of the taxpayer. Moreover, political affiliation is examined by studying the political party of the original appointing president of the judge. Because Special Trial Judges are not appointed by the President, the political affiliation of the President in office at the time the Special Trial Judge is appointed will serve as the appointing President.

Figure 2. Litigated Cases Categorized by Activity from 1990-2014

\begin{tabular}{|c|c|c|}
\hline Type of Activities & Includes: & $\begin{array}{l}\text { Number of decisions } \\
\text { from this activity }\end{array}$ \\
\hline Horse Related Activities & $\begin{array}{l}\text { Horse Breeding, Racing, Showing, Training, Riding, Cutting, Farming, } \\
\text { Jumping, Sales, Leasing, Boarding, Polo Horse Sales and Training, } \\
\text { Steeple Horse Training and Racing Stable, Racking Horse Breeding, } \\
\text { Arabian Horse Breeding/Training, Equestrian, Thoroughbred Breeding }\end{array}$ & 54 \\
\hline $\begin{array}{l}\text { Movie and Music } \\
\text { Activities }\end{array}$ & $\begin{array}{l}\text { Music Promotion, Band Formation, TV/Book/Radio Development, } \\
\text { Christian Music, Qualified Film Production, Record Label Activities }\end{array}$ & 4 \\
\hline Farming/Cattle Activities & $\begin{array}{l}\text { Corn, Oat, Pig, Cattle-Raising, Cattle Ranching, Wood, Fruit, Vegetable, } \\
\text { Organic Beef, Tree, Hay, Soy Bean, Cow, Dairy, Organic Apple } \\
\text { Orchard, Timber, Game-Bird Breeding, Sheep, Chicken, Peacock, Cattle } \\
\text { Breeding, Big Game Hunting }\end{array}$ & $16^{*}$ \\
\hline Racing Activities & $\begin{array}{l}\text { Nascar, Camaro, Asphalt Track, Cross Country with Antique } \\
\text { Cars/Motorcycles, Drag, Stock Car, Motor Cross, Sprint Car Racing }\end{array}$ & 11 \\
\hline Dog Related Activities & $\begin{array}{l}\text { Kennel and Breeding Shetland Sheepdogs, Maltese Dog Breeding, Dog } \\
\text { Breeding, Showing, Judging }\end{array}$ & 3 \\
\hline Authoring Activities & Book Writing/Authoring Activities & 3 \\
\hline $\begin{array}{l}\text { Exotic Animal Related } \\
\text { Activities }\end{array}$ & Exotic Animal Breeding & 1 \\
\hline Aviation Activities & $\begin{array}{l}\text { Airplane Engine Restoration, Aircraft Rental, Jet Chartering, } \\
\text { Environmental Aviation, Maintenance, Airplane Remanufacturing }\end{array}$ & 6 \\
\hline Boating/Fishing Activities & $\begin{array}{l}\text { Parasailing, Watersled Rides, Equipment Rentals, Yacht Chartering, } \\
\text { Sailboat Chartering, Fishing Boat Chartering, Yacht } \\
\text { Rental/Refurbishing, Commercial Fishing, Tournament Fishing, Bass } \\
\text { Fishing }\end{array}$ & 9 \\
\hline Energy Related Activities & Solar Energy Sales and Windmill Ethanol Distillery & 2 \\
\hline Art Related Activities & Photography, Drawings, Artist Activities & 7 \\
\hline Mining Related Activities & Metal Mining and Refinery & 2 \\
\hline Train Related Activities & Model Railroads & 1 \\
\hline Videotape Activities & Videotape Activities & 1 \\
\hline $\begin{array}{l}\text { Software Related } \\
\text { Activities }\end{array}$ & Computer Software Development & 1 \\
\hline
\end{tabular}

(Figure 2 continued on next page) 
(Figure 2 continued)

\begin{tabular}{l|l|c}
\hline \multicolumn{1}{c}{ Type of Activities } & \multicolumn{1}{c}{ Includes: } & $\begin{array}{c}\text { Number of decisions } \\
\text { from this activity }\end{array}$ \\
\hline Jade Related Activities & Jade Activities & 1 \\
\hline Amway Distributorships & Amway Distributorships & 2 \\
\hline Sports Related Activity & Volleyball and Bowling & 2 \\
\hline Talent Agency & Talent Agency & 1 \\
\hline Gambling Activity & Slot Machine & 1 \\
\hline Consulting Activity & International Consulting & 1 \\
\hline Space Related Activity & Space Exploration & 1 \\
\hline $\begin{array}{l}\text { Construction Related } \\
\text { Activity }\end{array}$ & Construction & 1 \\
\hline $\begin{array}{l}\text { Real Estate and Rental } \\
\text { Activity }\end{array}$ & $\begin{array}{l}\text { Real Estate, Rental, Property Rental, Timeshare Rental, Equipment } \\
\text { *Include }\end{array}$ & 6 \\
\hline
\end{tabular}

*Includes two decisions also included in horse related activities since both farming and horse related activities are discussed in the case.

The purpose of this study is to construct a logistic model capable of identifying the significant factors used in determining whether an activity is undertaken with a profit motive. This model will serve individual taxpayers contemplating litigation over an activity being deemed a hobby by the Service. Also, it may help taxpayers plan the organization of their activity to avoid scrutiny from the IRS and potential disallowance of losses.

\section{RESULTS}

The results of this research suggest that although nine factors have been described in the Treasury Regulations as guidance in the Tax Court's decision-making process, one factor tends to be more significant than the others. The implementation of the backward stepwise logistic regression builds a one variable model after the removal of the other eight variables. This significant factor is the manner in which the taxpayer carries on an activity. Table 2 shows that the $p$-value for the manner of the activity is less than 0.0001 indicating significance at the $0.10,0.05$, and 0.01 significance levels.

Table 1. Results of the Backwards Stepwise Logistic Regression Using Nine Factors Outlined in Treasury Regulation Section $1.183-2(b)$

\begin{tabular}{l|c|c|c|c|c}
\hline \multicolumn{5}{|c}{ Analysis of Maximum Likelihood Estimates } \\
\multicolumn{1}{c|}{ Parameter } & DF & Estimate & $\begin{array}{c}\text { Standard } \\
\text { Error }\end{array}$ & $\begin{array}{c}\text { Wald } \\
\text { Chi-Square }\end{array}$ & Pr $>$ ChiSq \\
\hline Intercept & 1 & -0.9685 & 0.5829 & 2.7607 & 0.0966 \\
\hline Manner & 1 & -4.1584 & 0.7644 & 29.5922 & $<.0001$ \\
\hline
\end{tabular}

Table 3 below depicts the results of predicting the decision of the court by using the one-factor model and then compares it to the actual decision made. Of the 38 decisions with a for-profit holding, 35 were predicted correctly with the model created in this study. Conversely, with 97 decisions having a hobby activity rendering, 95 were accurately forecasted. The overall accuracy of the model is capable of predicting $96.3 \%$ (130 of the 135 decisions) of the U.S. Tax Court holdings. 
Table 2. Results of Backwards Stepwise Logistic Regression in Predicting the Judge's Decision

\begin{tabular}{l|c|c|c}
\hline \multicolumn{1}{c}{ Decision } & For Profit & Prediction & Total \\
\hline \multirow{3}{*}{ For Profit } & 35 & 3 & 38 \\
& 25.93 & 2.22 & 28.15 \\
\hline \multirow{3}{*}{ Hobby } & 92.11 & 7.89 & \\
\cline { 2 - 4 } & 94.59 & 3.06 & 97 \\
\hline \multirow{2}{*}{ Total } & 2 & 95 & 71.85 \\
\hline & 1.48 & 70.37 & \\
\hline
\end{tabular}

This model provides important insight into how judges weigh the different factors and may assist taxpayers in how they structure their activities in the event the Service challenges the activity's tax treatment. Another important aspect of this research is the study of the judge's gender and whether that gender plays a role in how the decisions are being rendered. The results of the Chi-Square test are located in Table 4 below.

Table 3. Results of Chi-Square Test of Judge's Gender and Decision in the Cases

\begin{tabular}{l|c|c|c}
\hline \multirow{2}{*}{ Decision } & Female & Judge Gender & Total \\
\hline For Profit & 13 & 25 & 38 \\
\hline Hobby & 19 & 78 & 97 \\
\hline Total & 32 & 103 & 135 \\
\hline Pearson Chi2 $(1)=3.2283, \mathrm{Pr}=0.072$ & & &
\end{tabular}

The results suggest a statistically significant difference based on judge gender with a p-value of 0.072 at the 0.10 significance level. Based on the U.S. Tax Court's current gender makeup, taxpayers can weigh the likelihood of getting a certain judge gender. Table 5 shows the outcome from running the Chi-Square test between judicial outcome and political affiliation of the judge.

Table 4. Results of Chi-Square Test of Judge's Political Affiliation and Decision in the Cases

\begin{tabular}{l|c|c|c}
\hline \multirow{2}{*}{ Decision } & \multicolumn{2}{c}{ Judge Political Affiliation } & \multicolumn{2}{c}{ Total } \\
\cline { 2 - 4 } & Democrat & Republican & 38 \\
\hline For Profit & 9 & 29 & 97 \\
\hline Hobby & 28 & 69 & 135 \\
\hline Total & 37 & 98 & \\
\hline Pearson Chi2 $(1)=0.368, \operatorname{Pr}=0.544$ & & & \\
\hline
\end{tabular}

The findings of the Chi-Square test fail to indicate a statistically significant difference based on political affiliation with a p-value of 0.544 . This discovery is not unexpected and may suggest that the judges are free from bias.

\section{CONCLUSIONS}

Distinguishing between a hobby activity and a for-profit activity remains a highly litigated area of taxation. Specific guidance has been provided by the Service in Regulation Sec. 1.183. Nonetheless, these nine factors are evaluated based on the facts and circumstances of each individual case. Additionally, no one factor is indicative of a hobby activity or a for profit activity. Because of the nature of this tax area, every individual is potentially affected by this tax issue. If an activity is categorized as a for-profit activity, losses can exceed income from the activity, thereby, directly reducing the taxpayer's tax liability. The one variable (manner in which the taxpayer carries on the activity) model created in this study will provide an important framework. That is, taxpayers will be able to structure their 
activities in the future so that losses incurred can be used to lower an individual's tax liability. Also, the decision to litigate can also be better evaluated based on likelihood of judge gender assignment.

One potential limitation is the information detailed in the case briefs. If a court memo fails to list evidence in the case brief that has affected the judge's decision, that fact will be considered "neutral," thereby, potentially impacting the results found. Future research can use similar methodology to find significant factors in the dealer versus investor dilemma and to investigate the impact of judge gender and political affiliation in this arena.

\section{AUTHOR BIOGRAPHIES}

Ted D. Englebrecht is a Smolinski Eminent Scholar Chair Emeritus in Accountancy at Louisiana Tech University. Ted received his Ph.D. in Accounting from University of South Carolina, his Master of Accountancy from University of South Carolina, Master of Business Administration from East Carolina University, and Bachelor of Science in Business Administration from East Carolina University.

W. Brian Dowis is an Assistant Professor of Accounting at Georgia Southern University. Brian received his DBA in Accounting from Louisiana Tech University, his Master of Professional Accountancy from Clemson University, and his Bachelor of Science in Business Administration from Coastal Carolina University.

Justin S. Cox is a Doctoral student at University of Mississippi. Justin received his Master of Business Administration from Louisiana Tech University and his Bachelor of Science in Business Administration from Coastal Carolina University.

\section{REFERENCES}

Brennan, P.J. (2005). The tax court's interpretation of the hobby loss factors-a score sheet with analysis. Taxes-The Tax Magazine, July, 37-48.

Burns, J.O., \& Groomer, S.M. (1980). Effects of section 183 on the business/hobby controversy. Taxes-The Tax Magazine, March, 195-206.

Burns, J.O., \& Groomer, S.M. (1983). An analysis of tax court decisions that assess the profit motive of farming-oriented operations. The Journal of the American Taxation Association, Fall, 23-39.

Englebrecht, T.D., \& Dowis, W.B. (2016). An empirical assessment of employee vs. independent contractor status in taxation and the effects of judge's gender, political affiliation, and industry on those decisions. Forthcoming in Advances in Accounting Behavioral Research.

Hair, J.F., Black, W.C., Babin, B.J., Anderson, R.E., \& Tatham, R.L. (2006). Multivariate data analysis: Sixth Edition. New Jersey: Pearson Prentice Hall.

Jackson, M., Pippin, S., \& Wong, J.A. (2013). Asset and business valuation in estate tax cases: The roles of the court. JATA, 35 (2), 121-134.

Johnson, D.E. (1998). Applied multivariate methods for data analysts. Pacific Grove: Duxbury Press.

Previti, L., Kleinsmith, W., \& Previti, M. (2016). Hobbies versus business activities: the tax court's analysis. Journal of Taxation of Investments, 33(3), 65-76.

Robison, J. (1983). Tax court classification of activities not engaged in for profit: Some empirical evidence. The Journal of the American Taxation Association, 5(1), 7-22.

Siddiqui, S.M. (2013). A practical look at the hobby loss rule: determining factors in recent court cases. The CPA Journal, August, 46-48.

Walker, T.G., \& Barrow, D.J. (1985). The diversification of the federal bench: Policy and process ramifications. The Journal of Politics, 47(2), 596-617.

Welch, S. (1985). Are women more liberal than men in the U.S. Congress? Legislative Studies Quarterly, 10(1), $125-134$. 


\section{Appendix A}

\section{U.S. Treasury Regulation Section 1.183-2(b) Factors}

1. Manner in which the taxpayer carries on the activity. The fact that the taxpayer carries on the activity in a businesslike manner and maintains complete and accurate books and records may indicate that the activity is engaged in for profit. Similarly, where an activity is carried on in a manner substantially similar to other activities of the same nature which are profitable, a profit motive may be indicated. A change of operating methods, adoption of new techniques or abandonment of unprofitable methods in a manner consistent with an intent to improve profitability may also indicate a profit motive.

2. The expertise of the taxpayer or his advisors. Preparation for the activity by extensive study of its accepted business, economic, and scientific practices, or consultation with those who are expert therein, may indicate that the taxpayer has a profit motive where the taxpayer carries on the activity in accordance with such practices. Where a taxpayer has such preparation or procures such expert advice, but does not carry on the activity in accordance with such practices, a lack of intent to derive profit may be indicated unless it appears that the taxpayer is attempting to develop new or superior techniques which may result in profits from the activity.

3. The time and effort expended by the taxpayer in carrying on the activity. The fact that the taxpayer devotes much of his personal time and effort to carrying on an activity, particularly if the activity does not have substantial personal or recreational aspects, may indicate an intention to derive a profit. A taxpayer's withdrawal from another occupation to devote most of his energies to the activity may also be evidence that the activity is engaged in for profit. The fact that the taxpayer devotes a limited amount of time to an activity does not necessarily indicate a lack of profit motive where the taxpayer employs competent and qualified persons to carry on such activity.

4. Expectation that assets used in activity may appreciate in value. The term "profit" encompasses appreciation in the value of assets, such as land, used in the activity. Thus, the taxpayer may intend to derive a profit from the operation of the activity, and may also intend that, even if no profit from current operations is derived, an overall profit will result when appreciation in the value of land used in the activity is realized since income from the activity together with the appreciation of land will exceed expenses of operation. See, however, paragraph (d) of $\S 1.183-1$ for definition of an activity in this connection.

5. The success of the taxpayer in carrying on other similar or dissimilar activities. The fact that the taxpayer has engaged in similar activities in the past and converted them from unprofitable to profitable enterprises may indicate that he is engaged in the present activity for profit, even though the activity is presently unprofitable.

6. The taxpayer's history of income or losses with respect to the activity. A series of losses during the initial or startup stage of an activity may not necessarily be an indication that the activity is not engaged in for profit. However, where losses continue to be sustained beyond the period which customarily is necessary to bring the operation to profitable status such continued losses, if not explainable, as due to customary business risks or reverses, may be indicative that the activity is not being engaged in for profit. If losses are sustained because of unforeseen or fortuitous circumstances which are beyond the control of the taxpayer, such as drought, disease, fire, theft, weather damages, other involuntary conversions, or depressed market conditions, such losses would not be an indication that the activity is not engaged in for profit. A series of years in which net income was realized would of course be strong evidence that the activity is engaged in for profit.

7. The amount of occasional profits, if any, which are earned. The amount of profits in relation to the amount of losses incurred, and in relation to the amount of the taxpayer's investment and the value of the assets used in the activity, may provide useful criteria in determining the taxpayer's intent. An occasional small profit from an activity generating large losses, or from an activity in which the taxpayer has made a large investment, would not generally be determinative that the activity is engaged in for profit. However, substantial profit, though only occasional, would generally be indicative that an activity is engaged in for profit, where the investment or losses are comparatively small. Moreover an opportunity to earn a substantial ultimate profit in a highly speculative 
venture is ordinarily sufficient to indicate that the activity is engaged in for profit even though losses or only occasional small profits are actually generated.

8. The financial status of the taxpayer. The fact that the taxpayer does not have substantial income or capital from sources other than the activity may indicate that an activity is engaged in for profit. Substantial income from sources other than the activity (particularly if the losses from the activity generate substantial tax benefits) may indicate that the activity is not engaged in for profit especially if there are personal or recreational elements involved.

9. Elements of personal pleasure or recreation. The presence of personal motives in carrying on of an activity may indicate that the activity is not engaged in for profit, especially where there are recreational or personal elements involved. On the other hand, a profit motivation may be indicated where an activity lacks any appeal other than profit. It is not, however, necessary that an activity be engaged in with the exclusive intention of deriving a profit or with the intention of maximizing profits. For example, the availability of other investments which would yield a higher return, or which would be more likely to be profitable, is not evidence that an activity is not engaged in for profit. An activity will not be treated as not engaged in for profit merely because the taxpayer has purposes or motivations other than solely to make a profit. Also, the fact that the taxpayer derives personal pleasure from engaging in the activity is not sufficient to cause the activity to be classified as not engaged in for profit if the activity is in fact as evidenced by other factors whether or not listed in this paragraph. 


\section{Appendix B}

\section{U.S. Tax Court Cases listed in alphabetical order spanning 1990-2014}

Annuzzi, Mel A., et ux., TC Memo 2014-233 (2014)

Bailey, F. Lee, et al., TC Memo 2012-96 (2012) ${ }^{3}$

Barker, Donald C., TC Memo 2012-77 (2012)

Beauchamp, Kim, TC Memo 1997-393 (1997)

Berry, Fred B., et ux., TC Memo 2000-109 (2000)

Betts, Linda K., TC Memo 2010-164 (2010)

Blackwell, Mark E., et ux., TC Memo 2011-188 (2011)

Borsody, Frank J., TC Memo 1993-534 (1993)

Bowles, John D., TC Memo 1993-222 (1993)

Bronson, Peter C., et ux., TC Memo 2012-17 (2012)

Budin, Elbert, TC Memo 1994-185 (1994)

Bush, Christopher J., et ux., TC Memo 2002-33 (2002)

Callahan, Dudley Joseph, et ux., TC Memo 1996-65 (1996)

Chandler, Jo Anne M., TC Memo 2010-92 (2010)

Chow, John F., et ux., TC Memo 2010-48 (2010)

Christine, Willard M., et ux., TC Memo 2010-144 (2010)

Connolly, Michael J., TC Memo 1994-218 (1994)

Crail, Barbara Jean, TC Memo 1993-40 (1993)

Crile, Susan, TC Memo 2014-202 (2014)

Davis, Harvey J., et ux., TC Memo 2000-101 (2000)

Dawson, Steven F., et ux., TC Memo 1996-417 (1996)

Dennis, Jr., Johnny L., et ux., TC Memo 2010-216 (2010)

Dickie, Paul F., TC Memo 1999-138 (1999)

Dodds, William R., TC Memo 2013-76 (2013)

${ }^{3}$ Contains two decisions 
Dunkel, James C., TC Memo 1991-336 (1991)

Dunwoody, Kenneth R., TC Memo 1992-721 (1992)

Dwyer, Paul, et al., TC Memo 1991-123 (1991) ${ }^{4}$

Easter, Eddie J., TC Memo 1992-188 (1992)

Eldridge, Danny K., et ux., TC Memo 1995-384 (1995)

Emerson, Alton F., TC Memo 2000-137 (2000)

Filios, Louis A., et al., TC Memo 1999-92 (1999)

Flanagin, William E., et ux., TC Memo 1999-116 (1999)

Foster, Logene L., et ux., TC Memo 2012-207 (2012)

Giles, Elizabeth, TC Memo 2005-28 (2005)

Giles, Elizabeth, TC Memo 2006-145 (2006)

Glenn, Richard W., et ux., TC Memo 1995-399 (1995)

Goforth, James M., et ux., TC Memo 1999-356 (1999)

Haladay, Raymond R., TC Memo 1990-45 (1990)

Hart, William B., et ux., TC Memo 1995-55 (1995)

Hastings, Joyce E., TC Memo 2002-310 (2002)

Helmick, Marcia T., et ux., TC Memo 2009-220 (2009)

Hilliard, General K., et ux., TC Memo 1995-473 (1995) ${ }^{5}$

Hoyle, Jr., Lawrence T., TC Memo 1994-592 (1994)

Johnson, Jr., Christopher W., et ux., TC Memo 2012-231 (2012)

Johnson, Gerald G., TC Memo 1992-358 (1992)

Johnston, III, S.K., et ux. et al., TC Memo 1997-475 (1997) ${ }^{6}$

Jorman, Jr., John K., et ux., TC Memo 1994-613 (1994)

Joubert, Hubert, TC Memo 1992-184 (1992)

Kamholz, Gordon F., TC Memo 1990-192 (1990)

${ }^{4}$ Contains two decisions

${ }^{5}$ Contains three decisions

${ }^{6}$ Contains four decisions 
Kaufman, Richard L., TC Memo 1994-305 (1994)

Keating, Nora E., et vir., TC Memo 2007-309 (2007)

Knudsen, Dennis L., et ux., TC Memo 2007-340 (2007)

Krebs, David, TC Memo 1992-154 (1992)

Kurzet, Stanley M., et ux., TC Memo 1997-54 (1997)

Larson, Sr., Ronald Dale, TC Memo 1991-99 (1991)

Lencke, James J., et ux., TC Memo 1997-284 (1997)

Lombard, Emanuel S., TC Memo 1994-154 (1994)

Lowe, Steve L., et ux., TC Memo 2010-129 (2010)

Lundquist, Courtney, et ux., TC Memo 1999-83 (1999)

Machado, Joseph E., et al., TC Memo 1995-526 (1995)

Marcy, William L., TC Memo 1994-534 (1994)

Marvin, Raymond B., et ux., TC Memo 1999-362 (1999)

Massingill, Mark, et ux., TC Memo 1996-162 (1996)

Mathis, Travis A., et ux., TC Memo 2013-294 (2013)

Matlock, Robert, TC Memo 1992-324 (1992)

McCarthy, Anthony J., TC Memo 2000-135 (2000)

McEntyre, Jimmie A., TC Memo 1990-179 (1990)

McGuire, Michael R., TC Memo 1992-542 (1992)

McKeever, Richard J., et ux., TC Memo 2000-288 (2000)

McMillan, Denise C., TC Memo 2013-40 (2013)

McNaught, Dana L., TC Memo 1999-25 (1999)

Meaney, Thomas F., TC Memo 1994-91 (1994)

Misko, Jr., Fred, et ux., TC Memo 2005-166 (2005)

Mitchell, Austin L., et ux., TC Memo 2006-145 (2006)

Montagne, Brad, et ux., TC Memo 2004-252 (2004)

Nelson, Ruth N., TC Memo 2001-117 (2001) 
Nissley, Kenneth J., et ux., TC Memo 2000-178 (2000)

Novak, Louis J., TC Memo 2000-234 (2000)

Parker, John G., et ux., TC Memo 2002-76 (2002)

Pederson, Trilby, TC Memo 1994-555 (1994)

Phillips, Bruce E., TC Memo 2013-215 (2013)

Phillips, Eugene J., et ux., TC Memo 1997-128 (1997)

Piszczek, Walter J., TC Memo 1998-307 (1998)

Price, III, Raymond, et ux., TC Memo 2014-253 (2014)

Rabinowitz, Leonard, et ux., TC Memo 2005-188 (2005)

Rinehart, Dale Allan, TC Memo 1998-205 (1998)

Rohr, Gerald A., TC Memo 1993-373 (1993)

Rozzano, Jr., Michael J., et ux., TC Memo 2007-177 (2007)

Romer, Nicholas M., TC Memo 1998-238 (1998)

Routon, Robert A., et ux., TC Memo 2002-7 (2002)

Rowden, Robert L., TC Memo 2009-41 (2009)

Rundlett, Douglas, et ux., TC Memo 2011-229 (2011)

Sanders, Dean L., et ux., TC Memo 1999-208 (1999)

Sandoval, Robert G., et ux., TC Memo 2010-208 (2010)

Scheidt, Richard C., TC Memo 1992-9 (1992)

Schlievert, Patrick, et ux., TC Memo 2013-239 (2013)

Schwartz, Carl I., TC Memo 1991-380 (1991)

Sernett, John A., TC Memo 2012-334 (2012)

Shane, Michael T., TC Memo 1995-504 (1995)

Smith, Rhett Rance, et ux., et al., TC Memo 2007-368 (2007) ${ }^{7}$

Snoddy, Ronald W., TC Memo 1991-251 (1991)

Spear, Joseph, TC Memo 1994-354 (1994)

${ }^{7}$ Contains three decisions 
Stasewich, Richard A., TC Memo 1996-302 (1996)

Stasewich, Richard A., TC Memo 2001-30 (2001)

Stephens, Carroll J., TC Memo 1990-376 (1990)

Stephens, Mark A., TC Memo 1991-383 (1991) ${ }^{8}$

Storey, Lee, et vir., TC Memo 2012-115 (2012)

Strode, Kurt A., TC Memo 2012-59 (2012)

Sullivan, James L., et ux., TC Memo 1998-367 (1998)

Tinnell, James, TC Memo 2001-106 (2001)

Tirheimer, Wenzel, TC Memo 1992-137 (1992)

Trupp, Robin S., TC Memo 2012-108 (2012)

Verrett, III, Leon S., et ux., TC Memo 2012-223 (2012)

Vitale, Jr., Ralph Louis, TC. Memo 1999-131 (1999)

Wesinger, Jr., Ralph E., et ux., TC Memo 1999-372 (1999) ${ }^{9}$

Whalley, Barry D., et ux., TC Memo 1996-533 (1996)

Wheeler, Frank K.B., TC Memo 1999-56 (1999)

Wilmot, Wayne L., TC Memo 2011-293 (2011)

Windisch, Deborah Joyce, TC Memo 1996-369 (1996)

Yates, Lee W., et ux., TC Memo 1996-499 (1996)

Zarins, Andris, et ux., TC Memo 2001-68 (2001)

Zdun, Terry F., et ux., TC Memo 1998-296 (1998)

Zenzen, Ronald J., TC Memo 2011-167 (2011)

Zidar, Tony L., et ux., TC Memo 2001-200 (2001)

${ }^{8}$ Contains two decisions

${ }^{9}$ Contains two decisions 